\title{
Performance Analysis Based on Balanced Scorecard at Cooperative in Cianjur District - Indonesia
}

\author{
Rivani $^{1}$, Herwan Abdul Muhyi ${ }^{2}$, Zaenal Muttaqin ${ }^{3}$ \\ Department of Business Administration, University of Padjadjaran, Indonesia
}

\begin{abstract}
This research was conducted with the main aim to analyze the performance of a cooperative in Cianjur District using the Balanced Scorecard concept. Assessment of the Balanced Scorecard based performance is basically a performance appraisal uses integrated four main perspectives, namely: the financial perspective, customer perspective, internal business process perspective and learning and growth perspective. Research method used in this research was a case study method, with the type of analytical descriptive research. The case taken on this study was the Koperasi Unit Desa (KUD) "Cipanas" in Cipanas Sub-district, Cianjur District. This KUD selected because the object wasone of cooperation with a large enough scale and have a history of proudly enough performance. The research population on these cooperatives were the entire board and the employees of cooperative: 32 persons. The sampling technique used in this research wascensus, which mean all members of populationwassample, since the population size was not too large. For the validity of data, this study used trigulasi techniques, both source and data collection techniques.The conclusions of results of KUD “Cipanas" performance measurement based on Balanced Scorecard as measured from 4 perspectives, namely financial, customer, internal business processes, and growth and learning, generally speaking, was good. This can be seen from the financial ratio, the level of member services, and the use of computer-based operating system that had working well. However, there were still some things that need to be improved, including improving business efficiency and competence of members, especially new members.
\end{abstract}

Keywords: Balanced Scorecard, Cooperative

\section{Introduction}

Considering the great function and the important role of cooperatives on the progress of people economy, Indonesia should put special attention to the development of this cooperative institution. But when looking at cooperative data in Indonesia, it has not realized. According to BPS data in 2004 , the number of cooperatives in Indonesia was 89,939 units, while its contribution to GDP was estimated to be less than $4 \%$. This showed that the role of cooperatives was still very small compared with other business sectors. This phenomenon showed that the performance of cooperatives in general in Indonesia was still not optimal. This condition was not different from the existing cooperatives in Cianjur regency, West Java Province.

Cianjur, is a district in the province of West Java, is an area that has abundant natural wealth, especially in agriculture and plantation. This is seen on the official site of the district government which states that the majority of employment is mainly in the agricultural sector with the amount of $62.99 \%$ and this sector is also the largest contributor to Cianjur Gross Regional Domestic Product which is $42.80 \%$. With the condition and the potential of this nature, it is reasonable that the institutions supporting this sector are also growing rapidly, including cooperatives. Recorded on the data of the cooperative department of the Cianjur District, in 2006 there were 1027 cooperatives in its district. Unfortunately, with the high number of these cooperatives, it did not mean the role of cooperatives have been optimally support the people economy in Cianjur. This was demonstrated by the existence of some problems on the cooperatives in Cianjur, including: information from the head of the Cianjur Cooperative Department stated that from a thousand cooperatives in Cianjur, only about $10 \%$ or 150 cooperatives were still perform RAT (annual budget meeting) routinely. Also explained that from 150 cooperatives were still active today, only $2 \%$ of them were functional cooperatives with relatively healthy category. The other $8 \%$ were independent cooperatives. Though ideally, to be able to empower the people economy, the largest role was on independent cooperative. Another problem arises when the fake cooperatives allegedly increasingly widespread in Cianjur. It was shown that the high level of congestion of credit aid of farming business from central government in the range of 1997 to 2000 amounting to Rp. 354 billion, to many cooperatives in Cianjur. According to the head of R\&D center of Agribusiness Cooperatives in Cianjur, estimated until the year 2002, the level of non-performing loans amounted to Rp. 206 billion. Though the funds of that amount, if managed professionally by the cooperative, will contribute positively to the level of people's economy. Furthermore, problems were also found in the existence of cooperative functions that have changed from the ideal purpose and function of the cooperative. This was marked by the rise of loan sharks under the guise of savings and credit cooperatives (SCC), which of course will make it more difficult for the commoners. The loan sharks who call themselves SCC, in practice was far from the basic functions of the cooperative. The term "save" is only a cover, and they drive customers to borrow money at high rates of interest. If the customer is unable to pay, they will charged by high interest and multiplied fine, and if the contract has expired but it still in arrears, then the credit contract will extended and credit interest or loan will doubled again. On "Pelita" the daily newspaper, Thursday, January 24, 2008, it was stated that since several years, the loan sharks under the guise of CSS in Cianjur were rise significantly especially in the areas of Karangtengah and Ciranjang sub-districts. The target of his working area covers the areas of Karangtengah, Cikalongkulon, Cianjur Kota, Mande, Ciranjang, Bojongpicung, Warungkondang, Cibeber and several districts in South Cianjur.

Based on that phenomenon, some of these problems did not seem to be explored optimally. It becaused the cooperatives

Volume 6 Issue 7, July 2017 


\section{International Journal of Science and Research (IJSR) \\ ISSN (Online): 2319-7064}

Index Copernicus Value (2015): 78.96 | Impact Factor (2015): 6.391

in performing its performance assessment has not been optimal. By far, cooperatives did performance evaluation only based on annual financial statements, so that performance can be seen only in terms of finance and production. Whereas not rare the cooperatives become inactive, then eventually bankrupt, due to lack of ability to manage their cooperatives. Based on that background, in order to find more optimal performance appraisal standard, it is necessary to conduct research with the title "Performance Analysis based on Balanced Scorecard Based at Cooperative in Cianjur Regency".

\section{Research Objective}

The main objective to be achieved from this research was to get an overview of the performance of a Cooperative in Cianjur District based on balanced scorecard performance assessment.

\section{Literature Survey}

One of the organizations needs to grow is to conduct regular performance appraisals, so that the organization has guidelines for improvement. Various concepts that can be used to measure the performance of organization, one of which is the concept of Balanced Scorecard. This concept began to be used when it was known to have an advantage in measuring the organizational aspects more comprehensive and more able to align with strategic planning organization.

\subsection{Performance Assessment Based on Balanced Scorecard}

In line with the growth of organizational performance appraisal, the concept of the old model performance measure is being abandoned, as the objective is considered to be the only short-term profitability. Leaders of organizations that only require employees to optimize profits usually apply performance measures the dimension of profitability only. The elements measured in this case are usually sales, cashflow, capital expenditure, costs, assets, debt, liabilities and so on (Martini Kuseini: 1997).

The measures above is organizationally more easily measured in a qualitative manner, so that external aspects are overlooked, such as the level of customer satisfaction, customer loyalty, employee retention, etc., so profit-oriented organizations can not guarantee their sustainability in hypercompetitive global competition . Therefore, Kaplan and Norton (1996) introduced the Balanced Scorecard concept as a measuring system that tries to balance the old measurement tools with dimension of profitability only, with new dimensions as balancing elements. By the scorecard that balanced is expected to integrate the organization's energy and organizational knowledge more specifically from the organization in order to achieve more long-term goals.

Regarding the definition of Balanced Scorecard, according to Kaplan and Norton (2000): Balanced Scorecard is a measurement of corporate performance that translates mission and strategy into various objectives and measures composed into four perspectives: financial, customer, internal business processes, and learning growth. Scorecards provide frameworks, languages, to communicate missions and strategies. Scorecards use measurements to inform workers about the factors that drive current and future success.

From that definition, we can understand that the balance scorecard is a system of organizational performance measurement that can operationalize the mission and strategy of the company comprehensively and measurable.

The Balanced Scorecard itself examines four perspectives considered relevant to assess the performance of a business intensity. The four perspectives are: (1) financial perspective, (2) customer perspective, (3) internal business process perspective and (4) learning and growth perspective (Kaplan and Norton: 1996).

\subsection{The Concept of Cooperative}

Cooperative is a form of cooperation in the economy. This cooperation is held by people because of the similarity of their needs. These people work together on their daily needs, which related to the company as well as their household needs. To achieve that goal required a cooperation that will sustain, therefore they formed an association as a form of cooperation (Panji Anoraga: 2003)

The definition of cooperative according to the Cooperative Laws No.12 in 1967:

"Cooperative is a organization of populist economy with social character, consisting of cooperative legal persons or entities which constitute the economic order as a joint effort based on the principle of kinship".

Given the meaning by that, the cooperative has a big enough role in preparing the joint effort of people who have limited economic ability. This effort aims to meet a shared need, which ultimately raises self-esteem, improves the position and ability to defend itself and free itself from adversity.

In the cooperative, there are the main guidelines that inspirit and underlie every step of the business and cooperative work as a cooperative organization of people with limited economic ability. These guidelines are commonly referred as the principle or basic joints of the Cooperative. The basic joints of cooperatives in Indonesia according to the Law of 1967 article 6 are:

1) The nature of membership is voluntary and open to every Indonesian citizen.

2) Meeting of members is a supreme authority as a reflection of democracy within cooperatives.

3) The sharing of the profits shall be distributed based on the services of each member.

4) There are restrictions on interest on capital.

5) Developing the welfare of the members in particular and the society in general.

6) The business and its management are open.

7) Self-help, self-awareness and self-sufficiency as a reflection of the basic principle: believe in yourself. 


\section{International Journal of Science and Research (IJSR) \\ ISSN (Online): 2319-7064}

Index Copernicus Value (2015): 78.96 | Impact Factor (2015): 6.391

\section{Research Methods}

The type of research used in this study is analytical descriptive, which means to describe the existing phenomenon when this research was conducted (Masri Singarimbun, 1989). Research method used in this research was a case study method, with the type of analytical descriptive research. The case taken on this study was the "Cipanas" Cooperative in Cipanas Sub-district, Cianjur District. This Cooperative selected because the object was one of cooperation with a large enough scale and have a history of proudly enough performance. The research population on these cooperatives were the entire board and the employees of cooperative: 32 persons. The sampling technique used in this research was census, which mean all members of population was sample, since the population size was not too large. For the validity of data, this study used trigulasi techniques, both source and data collection techniques.

\section{Discussions and Results}

\subsection{Cooperative Performance Based on Balanced Scorecard}

In this section, will be exposed on the performance of "Cipanas" Cooperative in Cianjur District, with performance assessment tool based on balanced scorecard from Kaplan and Norton (2000). Unlike most other traditional performance measures, which rely more heavily on financial information as the main benchmark of organizational performance measurement, the balanced scorecard-based performance tool tries to measure organizational performance more comprehensively and integrated. With this balanced scorecard concept, the performance of "Cipanas" Cooperative will be measured from four perspectives, namely financial perspective, customer perspective, internal business process perspective, and learning and growth perspective. Performance measurement was done by distributing questionnaires to all administrators, management and employees at Cooperative "Cipanas" which amounted to 32 persons. In order to increase the objectivity and sharpness of the analysis, the results of the questionnaire tabulation are supplemented with observations and interviews. The following was the result of the performance measurement, starting from the performance of the cooperative based on the financial perspective.

\subsubsection{Performance of Cooperative "Cipanas" from Financial Perspective}

For this financial perspective, Cipanas Cooperative was measured by several indicators, namely operating income, gross profit, return on capital (ROE), return on investment (ROI), and from the rate of economic addition. Based on the questionnaire results, it was known that most respondents were answered "agree" was equal to $49 \%$, although respondents who answered "less agree" was also not a little that was equal to $39 \%$, while the remaining of $9 \%$ and $3 \%$ were respectively "strongly agree" and "disagree". This result was quite aligned when compared with the author's interview with Mr. Aan (chairman of Cipanas Cooperative) who stated that cooperative business volume recently could reached almost 3 Billion rupiahs, with a population of 2174 members. It was also continued in the last 2 years, that they can achieved profits up to $40 \%$, so that from operating income and gross profit can be considered high enough. However, they also admited that the level of efficiency of their business still needs to be improved again.

\subsubsection{Performance of Cipanas Cooperative from Customer Perspective}

The survival of a business organization depends on how the organization maintain its customers and at the same time acquires new ones. Similarly with Cipanas Cooperative, by the capacity to serve more than 2,000 members, it was required to have a good strategy in serving and finding customers, so it was a reasonable thing if the performance of the organization also consider from the perspective of the customer.

From the questionnaires, it can be concluded that the answer of most respondents was "agree" for the cooperative treatment in serving the customer was good, that was equal to $72 \%$. While the second most occupied by respondents who were "less agree" with the amount of $22 \%$, while the rest responded "strongly agree" and "not agree" with the amount of $4 \%$ and $1 \%$ respectively. The results of this questionnaires distribution were quite consistent with the results of observations and interviews of authors with some respondents, who stated that the number of their members from year to year increased. It recorded up to 2,174 in the year 2009, with the composition of the majority members are farmers as much as 1,959 persons, then members of the breeder group as many as 140 persons, and last group of general members as many as 105 persons. Nevertheless, the information from the respondents also stated that out of a number of these members, who really active were only around 150 persons.

\subsubsection{Performance of Cipanas Cooperative from Internal Business Process Perspective}

The most important factor of achieving customer satisfaction, beside services, also the quality of its products. In order to produce a product with good quality, demands a good operational system as well. In addition, innovation efforts in business processes are also needed to improve product quality so that can always win a tight business competition. Therefore, the next assessment of organizational performance is important to measure from the point of view of internal business processes, where dimensions are the degree of innovation to internal business processes, production process systems, and after-sales services to their internal business processes.

Based on the questionnaire, it was found out that most respondents stated "agree" to the organization's performance from the perspective of this customer was good, that was equal to $68 \%$. Meanwhile there were respondents who answered "less agree" and there was also an answer "strongly agree", that was equal to $22 \%$ and $1 \%$ only. This phenomenon was quite directly proportional when associated with the results of observations and interviews with some respondents who stated that they have realized that quality products and services that can only be generated from the process of quality operations as well. They were therefore very concerned about improving business 


\section{International Journal of Science and Research (IJSR) \\ ISSN (Online): 2319-7064}

Index Copernicus Value (2015): 78.96 | Impact Factor (2015): 6.391

processes, by monitoring them through "rapat minggon" or in English mean regular and ongoing monitoring processes in their business processes by weekly discussions.

\subsubsection{Performance of Cipanas Cooperative from Learning and Growth Perspective}

When the good business process factors, produce good services and products, so that consumers and customers feel satisfied and give positive impact on corporate profits financially, the next thing to note is the aspect of human resources that run the whole aspect of business. In the fierce business competition, professional Human Resources (HR), which not only have integrity and commitment to the company, also have the ability and willingness to always sharpen themselves to improve their competence. Therefore, the measurement of organizational performance also needs to be taken into account from the learning and growth perspective of all the resources in the organization. In this learning and growth perspective, the dimensions measured are the capabilities of human resources, the application of computerized information systems, and the level of motivation, initiative and empowerment of its human resources.

Based on the results of the questionnaire, it was stated that most respondents answered respondents "agree" that was $63 \%$, and the second most respondents who answered "strongly agree" by $22 \%$, then as much as $17 \%$ of all respondents who answered "disagree " on the dimensions of the learning process and growth of the organization has been well implemented. These positive responses were shown in the questionnaire, in line with the results of observations and interviews of researchers with some respondents. From the interviews obtained information that Cipanas Cooperative management was very concerned with the competence of managers and employees in managing the business unit. Because as good as any operational system was applied, if it was run by a person that was not competent, then the efforts to maximize the performance of the organization will still be in vain. Therefore, to meet the need of human resource competent upgrading, they often work with various dairy companies, or cooperatives and local Small Medium Enterprises (SMEs) to conduct trainings to improve their skills and improve their work standards. For training in cooperation with private parties, it usually worked smoothly, but for the training that run by the local government, it usually went the way it is, and it was as though only just to spend their budget.

\subsection{Barriers on Cipanas Cooperative Performance}

In conducting its business operations, based on interviews with some of its respondents, Cipanas Cooperative experienced several obstacles, among others were:

a) On the aspect of human resources, especially for new members, they were still need guidance and training in order to quickly adapt and contribute to the business development of this cooperation.

b) In production aspect, especially on milk quality was still lack of standard. This was recognized by the management of Cipanas Cooperative, who felt that the quality of cow's milk produced by their members was still lack of standard, both in terms of quantity and quality.

c) Aspects of capital, the cooperative had the ability to develop their business, but the obstacle was still difficult to find additional capital or parties who want to invest.

\section{Conclusions and Recommendations}

\subsection{Conclutions}

Performance Measurement is however required by any organization for the organization's business development. By knowing the performance of the organization has an opportunity to realize where the pontencies and constraints, and can seek more an appropriate strategy. This study analyzes the performance based on balanced scorecard on Cooperative in Cipanas sub-district, Cianjur District, in this case "Cipanas" Cooperative. Based on the research, there were several things that can be concluded, namely:

a) Cipanas, a cooperative in the sub-district of Cipanas, Cianjur district, and was a cooperative that had a good history with a variety award of local and national scales as a proof.

b) The results of performance measurement of Cipanas Cooperative based on Balanced Scorecard, which measured by 4 perspectives, namely: finance, customer, internal business process, and growth and learning, in general can be said was good. This can be seen from the financial ratio, the level of service members, and the use of computer-based operating system that had been running well. However, there were still some things that need to be improved, including business efficiency and increased the competency of members, especially new members.

c) Some obstacles in optimizing its performance were milk quality in milk dairy unit was still lack of standard, new members were still lack of competence, and the level of business efficiency was still poor.

\subsection{Recommendations}

Based on those conclusions and obstacles, there were several things that can be considered as suggestions, namely:

a) It was better that Cipanas Cooperative to analyze the operational system in order to find the potential waste of operations on each business unit. So if there was in the sub-system operation occurs the inefficiency, it can be considered and follow up with the anticipation strategies. The analysis of this operating system can be done internally by the cooperative itself, or by working with other competent organizations/institutions.

b) In order to improve the competent of members, especially the new members, beside to relying on traditional training methods that were usually carried out by the cooperative internal or work together with the goverment institutions/external parties, Cipanas Cooperative can also use other training methods to provide variation and to add training benefits optimally. The example of these other training methods were apprenticeship, case studies, group discussions, etc.

c) Although Cipanas Cooperative had been utilizing computer technology to support their operation, it would be better if this computer technology was utilized not 


\section{International Journal of Science and Research (IJSR) \\ ISSN (Online): 2319-7064}

Index Copernicus Value (2015): 78.96 | Impact Factor (2015): 6.391

only to support administrative work in a more narrow meaning again. But computer technology, when optimized with internal and external network systems (internet) can be utilized for the management of knowledge and accessed information from around the world that was useful in the business development of Cipanas Cooperative.

\section{References}

[1] Kaplan R.S. and Norton D.P. (1996). The Balanced Scorecard: Translating Strategy into Action. Harvard Business Review Press.

[2] Kaplan R.S. and Norton D.P.(2000). The StrategyFocused Organization. Harvard Business Review Press.

[3] Masri Singarimbun. (1989). Metode Penelitian Survey. Cetakan Pertama. Jakarta: LP3S.

[4] Panji Anoraga. (2003). Dinamika Koperasi. Jakarta: Rineka Cipta.

[5] Sony Yuwono. (2003). Balanced Scorecard Menuju Organisasi Yang Berfokus Pada Strategi. Jakarta: Gramedia.

Volume 6 Issue 7, July 2017 www.ijsr.net 